\title{
Determination of mRNA Expression of Typical Proteins of Tight Junctions in the Intestinal Mucosa of Broilers (Gallus gallus domesticus)
}

\author{
Elizabeth Aguirre García1 ${ }^{1}$ Carlos Ignacio Soto Zárate ${ }^{1}$, Francisco Rodolfo González Díaz' \\ José Luis Nieto Bordes ${ }^{1}$, Germán Isauro Garrido Fariña², Carlos Gerardo García Tovar
}

${ }^{1}$ Laboratorio 4 de Morfología Veterinaria y Biología Celular, Unidad de Investigación Multidisciplinaria, Facultad de Estudios Superiores Cuautitlán, Universidad Nacional Autónoma de México, Cuautitlán Izcalli, México ${ }^{2}$ Laboratorio de Apoyo a Histología y Biología. Facultad de Estudios Superiores Cuautitlán, Universidad Nacional Autónoma de México, Cuautitlán Izcalli, México Email: *cgarciatov@cuautitlan.unam.mx

How to cite this paper: Aguirre G.E., Soto Z.C.I., González D.F.R., Nieto, B.J.L. Garrido F.G.I. and García T.C.G. (2021) Determination of mRNA Expression of Typical Proteins of Tight Junctions in the Intestinal Mucosa of Broilers (Gallus gallus domesticus). Open Journal of Veterinary Medicine, 11, 212-225. https://doi.org/10.4236/ojvm.2021.116014

Received: May 12, 2021

Accepted: June 20, 2021

Published: June 23, 202

Copyright (อ 2021 by author(s) and Scientific Research Publishing Inc. This work is licensed under the Creative Commons Attribution International License (CC BY 4.0).

http://creativecommons.org/licenses/by/4.0/ (c) (i) Open Access

\begin{abstract}
Tight junctions are mainly formed by two types of proteins; claudins and occludin, both of which are fundamental to maintain the integrity and barrier function of the intestinal epithelium. This barrier function allows for the absorption of nutrients, mainly by transcytosis; however, in birds, $90 \%$ of the substances are absorbed by paracellular mechanisms. Despite this, claudins present in the different parts of the intestinal tract of adult chickens are not known, much less their functional role. This study aimed to determine the presence of mRNA of claudins $1,2,3,5,10,12,16$ and occludin, in the different regions of the intestine (duodenum, jejunum, ileum, cecum, and rectum) in chickens (Gallus gallus domesticus) through RT-PCR. To meet this goal, 7 weeks old roosters destined for slaughter and chicken embryos of 16 days of incubation (positive control) were used. For all the processed samples, amplicons of the expected size were obtained; claudin 1 (662 pb), claudin 2 (162 pb), claudin $3(185 \mathrm{pb})$, claudin $5(224 \mathrm{pb})$, claudin $10(687 \mathrm{pb})$, claudin $12(738 \mathrm{pb})$, claudin $16(191 \mathrm{pb})$ and occludin $(430 \mathrm{pb})$. To corroborate these findings, obtained amplicons were sequenced and, subsequently, a basic alignment was performed on the NCBI, obtaining a correlation of $100 \%$ with the original sequences in all analyzed samples. To our knowledge, the present work represents the first written report regarding the presence of mRNA of the main proteins involved in tight junction formation throughout the intestinal tract of domestic chickens of 7 weeks of age. These findings will allow elucidating the specific function of each of the reported proteins in the process of paracellular absorption in chickens.
\end{abstract}




\section{Keywords}

Chicken, mRNA, Claudins, Ocludin, Tight Junctions and RT-PCR

\section{Introduction}

Tight junctions are an element of the junction complex found in epithelial and endothelial cells, they form a belt between the plasmatic membrane lateral domain near the apical pole, which serves as a primary barrier to the diffusion of solutes, regulates paracellular transit, and enables cell polarization. Tight junctions are fundamental to maintain the integrity and paracellular barrier function of epithelium and endothelium cells [1] [2]. They restrict the movement of proteins between the basolateral and apical compartments, regulating the passage of ions and solutes through the paracellular space [1] [3].

Structurally, tight junctions are composed of proteinaceous filament nets, called strands which traverse the extracellular space to interact with the tight junctions of adjacent cells. The physiological property to act as a seal depends on several factors such as the number of strands, the amount of physical tension exerted on the seal, and the primary component of strands' proteins [4]. Tight junctions have been studied mainly in humans and mice, in these species, it was determined that the differentiation of claudins is evident along the length of the small intestine, where these proteins are vital for the appropriate absorption of nutrients [5].

The proteins that integrate tight junctions in mammals are occludin, claudins, tricellulin, junction adhesion molecule (JAM) and Marvel D3 [6]-[11].

Claudins are transmembrane proteins with a molecular weight ranging from 20 to $27 \mathrm{kDa}$, they polymerize linearly to form strands, establishing transcellular interactions in cis (between claudins of the same cell) and in trans (between claudins of adjacent cells), which determines paracellular permeability, epithelial polarization, and conservation of transepithelial resistance, as well as the selective passage of molecules and ions [1] [2].

This multigenic protein family consists of approximately 27 members in humans and mice [2] [4] [12] [13] [14], species in which most of these proteins have been studied, although their presence has also been observed in different organs in chicken embryos and adult birds [3] [15] [16] [17].

Claudins are grouped into two categories; sealing claudins $(1,3,4,5,11,14,18$ y 19) and channel-forming claudins (2, 10,12, 15, 16, 17, 19 y 21); some, like claudin 7 , can act as a barrier or a channel in a context-dependent way; claudins 2, 10 and 15 (passage of cations); claudins 10 and 17 (passage of anions); claudin 2 (passage of water). The differences in the density and/or tortuousness of the strands and/or proportion of the combination of members of this protein family determine the channel and barrier properties of the tight junctions [1] [3] [13]-[23] and, they also play a critical role in generating epithelial tubes, lumens, 
and tubular networks during organ formation [24].

Occludin is a highly conserved protein in mammals and birds [25]. It is present in cells that form tight junctions. The size of the occludin varies with the species; for example, in chickens, it is $55.9-62 \mathrm{kDa}$, while in human is $82 \mathrm{kDa}$ [12] [26] [27] [28]. This protein is not essential for the assembly of a tight junction, but it is important when limiting functional permeability [6].

The intestinal absorption occurs by the passage of molecules through the cell and by paracellular transit [6] [11] [29]. The paracellular transit works by one of the following mechanisms: the "pore" pathway, which is of low capacity and allows the passage of ions and small solutes. The "leakage" pathway allows the flow of small and large molecules (unloaded ions and solutes) in a non-selective manner. This pathway involves the breaking of strands or the transient formation of paracellular spaces [1] [30] [31].

Transcellular interactions are determined by the amino acid sequence of extracellular loops [32] [33] [34] [35]. The claudins form homotypic and heterotypic interactions, so there is considerable potential for various interactions and pore characteristics [36].

The digestive tract of the bird is shorter and simpler than that of mammals; however, it is highly efficient for digestion and nutrient absorption processes [37]. In the intestinal epithelium of birds, $90 \%$ of the substances (ions, nutrients, etc.) are absorbed through pores 4 to $8 \mathrm{~nm}$ in diameter, which is present in the tight junctions, this could explain why birds have a greater absorption capacity of water-soluble metabolites compared to mammals [8] [38]. Additionally, it has been reported that alterations in the expression of tight junctions' proteins cause alterations in the function of claudin-based paracellular barrier and are related to water imbalance, inflammation, cancer, and brain disease [1] [18].

Tight junctions play a preponderant role during intestinal absorption in birds. For this reason, it is essential to identify the claudins by the determination of the presence of claudin mRNA in the mucous tunic of the different regions of the intestine in chickens 7 weeks of age, which we consider a fundamental step on the way to elucidate their specific role.

\section{Materials and Methods}

\section{Primers Design}

For claudins 1 and 5 of chicken, the sequence was obtained from the Genbank and their primers were designed with Primer-blast and Primer3. The Oligo Calc program was used to determine the possible formation of dimers and secondary structures. For claudin 2 and 3, primers reported by Ozden et al. (2010) [39] were used; whereas for claudin 10 and 12 those reported by Collins et al. (2013) [3] were used. Chicken $\beta$-actin was used as a positive internal control, as were primers previously reported by Zhang et al. (2013) [19]. Finally, each primer was analyzed with Sequencher 5.2.4. program, this identified an error in the primers reported for claudin 10 and 12 , so the sequence was corrected. 


\section{Animals}

Three broilers with an average weight of $2.5 \mathrm{~kg}$ and 7 weeks of age were used. Chicken embryos with 16 days of incubation donated by the company Avimex were the positive control.

\section{Collection and preparation of samples}

We obtained samples of the duodenum, jejunum, ileum, cecum, and rectum. For this, the chickens were humanely slaughtered using carbon monoxide and following the guidelines stipulated in the Official Mexican Standard NOM-033-ZOO-1995 for the humanitarian slaughter of domestic and wild animals. All experimental procedures were approved by Institutional Animal Care and Use Committee (CICUAE-FESC). All the time, the samples were handled and kept at $4^{\circ} \mathrm{C}$. We obtained a sample of each of the intestinal segments by two transversal cuts. To expose the mucosal tunic, we made a longitudinal cut and removed all its content including the mucus. The mucosal tunic was recovered by scraping with a scalpel blade and placed in an Eppendorf tube with the lysis buffer from RNA Mini Kit PureLink TM (Invitrogen, cat. 12183018A). After we made the disgregation of tissue by sonication (Ultrasonic processor, model Gex 130). To verify that the obtained samples only contained intestinal mucosa, routine histological processing and staining with Hematoxylin and Eosin $(\mathrm{H}-\mathrm{E})$ of a representative sample was performed. It is important to note that due to the size of the embryos, the intestinal samples obtained were composed of the four structural tunics.

\section{RNA Extraction}

The extraction of the RNA of the various segments of the intestinal tract of the domestic chickens and the embryos was made with the RNA Mini Kit PureLink (Invitrogen, cat. 12183018A) following the manufacturer's instructions. The concentration and purity of RNA were determined by spectrophotometry (Table 1 and Table 2) and to evaluate its integrity, samples were subjected to electrophoresis in $1.5 \%$ agarose gels stained with ethidium bromide and observed on the transilluminator [40] (data not shown).

\section{RT-PCR}

For each of the genes, the synthesis of cDNA with reverse transcriptase of M-MLV was performed (Invitrogen, Cat. 28025013) and the quantity and purity of the cDNA were estimated. The presence of the different claudins was determined

Table 1. Amount of RNA obtained from the samples under study.

\begin{tabular}{cccccc}
\hline $\begin{array}{c}\text { Intestinal } \\
\text { portion }\end{array}$ & $\begin{array}{c}\text { Embryo with 16 days of } \\
\text { incubation }(\mathrm{ng} / \mu \mathrm{l})\end{array}$ & $\begin{array}{c}\text { Chicken 1 } \\
(\mathrm{ng} / \mu \mathrm{l})\end{array}$ & $\begin{array}{c}\text { Chicken 2 } \\
(\mathrm{ng} / \mu \mathrm{l})\end{array}$ & $\begin{array}{c}\text { Chicken 3 } \\
(\mathrm{ng} / \mu \mathrm{l})\end{array}$ & $\begin{array}{c}\text { Average adult } \\
\text { birds }(\mathrm{ng} / \mu \mathrm{l})\end{array}$ \\
\hline Duodenum & 1853.1 & 297.6 & 225.1 & 421 & 314.5 \\
Jejunum & 1519.2 & 274.2 & 120.2 & 77.9 & 157.4 \\
Ileum & 1137.9 & 118.5 & 1283.4 & 633.1 & 678.3 \\
Cecum & 2002.4 & 264.6 & 1398.7 & 1340 & 1001.1 \\
Rectum & 1996.6 & 70.9 & 269.2 & 844 & 394.7 \\
\hline
\end{tabular}


Table 2. Determination of purity of the obtained RNA (Ratio 260/280).

\begin{tabular}{cccccc}
\hline Intestinal portion & $\begin{array}{c}\text { Embryo with 16 } \\
\text { days of incubation }\end{array}$ & Chicken 1 & Chicken 2 & Chicken 3 & $\begin{array}{c}\text { Average } \\
\text { adult birds }\end{array}$ \\
\hline Duodenum & 2.09 & 2.12 & 2.16 & 2.06 & 2.11 \\
Jejunum & 2.11 & 2.09 & 2.26 & 2.50 & 2.28 \\
Ileum & 2.12 & 2.18 & 2.10 & 2.08 & 2.12 \\
Cecum & 2.10 & 2.12 & 2.10 & 2.12 & 2.11 \\
Rectum & 2.11 & 2.24 & 2.00 & 2.12 & 2.12 \\
\hline
\end{tabular}

Table 3. Primers used for the identification of claudins, occludin and $\beta$-actin genes.

\begin{tabular}{|c|c|c|c|c|}
\hline $\begin{array}{l}\text { Gen and access } \\
\text { number }\end{array}$ & Protein & Primer sequence $\left(5^{\prime}-3^{\prime}\right)$ & Size (pb) & Reference \\
\hline $\begin{array}{c}\text { Cldn } 1 \\
\text { NM_001013611.2 }\end{array}$ & Claudin 1 & $\begin{array}{l}\text { TGCCACTCCCTGATGTTTCC } \\
\text { AGGTCTCATAAGGCCCCACT }\end{array}$ & 662 & This work \\
\hline $\begin{array}{c}\text { Cldn } 2 \\
\text { XM_420271 }\end{array}$ & Claudin 2 & $\begin{array}{l}\text { CTCAGCCCTCCATCAAAC } \\
\text { TGCGTCTTCTCCTCTTAC }\end{array}$ & 162 & [44] \\
\hline $\begin{array}{c}\text { Cldn } 3 \\
\text { NM_204202 }\end{array}$ & Claudin 3 & $\begin{array}{l}\text { AGCCCTCCATCTCAGCAG } \\
\text { TTCTCCGCCAGACTCTCC }\end{array}$ & 185 & [44] \\
\hline $\begin{array}{c}\text { Cldn } 5 \\
\text { NM_204201.1 }\end{array}$ & Claudin 5 & $\begin{array}{l}\text { ATCTACATCCTCTGCGGGGT } \\
\text { TACTTGACGGGGAAGGAGGT }\end{array}$ & 224 & This work \\
\hline $\begin{array}{l}\text { cClaudin-10 } \\
\text { GI:118084678 }\end{array}$ & Claudin 10 & $\begin{array}{c}\text { GATGGCGAGCACGTCGGCGGAG } \\
\text { TTAAACGTAAGCGTTCTTGTC }\end{array}$ & 687 & [3] \\
\hline $\begin{array}{l}\text { cClaudin-12 } \\
\text { GI:118085731 }\end{array}$ & Claudin 12 & $\begin{array}{l}\text { ATGGGCTGCAGGGATGTTCAT } \\
\text { TTTAAGATGTGTGTGTCACAACA }\end{array}$ & 738 & [3] \\
\hline $\begin{array}{c}\text { Cldn } 16 \\
\text { XM_426702.2 }\end{array}$ & Claudin 16 & $\begin{array}{l}\text { CTGGCTTAACTCAGGGTGCA } \\
\text { GGGCTGCTGTGACCTTTACT }\end{array}$ & 191 & This work \\
\hline $\begin{array}{l}\text { Occludin } \\
\text { D21837.1 }\end{array}$ & Occludin & $\begin{array}{l}\text { GAGCTACAGCTACGGCTACG } \\
\text { CTTCTGGGCGAAGAAGCAGA }\end{array}$ & 430 & This work \\
\hline NM_205518 & $\beta$-actin & $\begin{array}{l}\text { TCTTGGGTATGGAGTCCTG } \\
\text { TAGAAGCATTTGCGGTGG }\end{array}$ & 331 & [19] \\
\hline
\end{tabular}

through the PCR endpoint. The oligonucleotides used for CDNA synthesis and amplification reaction are shown (Table 3). In all cases the reaction mixture was formed by: sterile bidistilled water, buffer $10 \times$ (Tris- $\mathrm{HCl} 200 \mathrm{mM} \mathrm{pH} \mathrm{8.4,} \mathrm{KCl}$ $500 \mathrm{mM})$, magnesium chloride $\left(\mathrm{MgCl}_{2}\right)$, dNTP's, Taq polymerase, and specific primers. The reaction mixtures were incubated under previously standardized conditions and programmed in a thermocycler. For all PCR reactions, the denaturation period was $30 \mathrm{sec}$ at $94^{\circ} \mathrm{C}$ and polymerisation was $1 \mathrm{~min}$ at $72^{\circ} \mathrm{C}$. For claudins 1,2 and 3 the alignment period was $30 \mathrm{sec}$ at $55^{\circ} \mathrm{C}, 56^{\circ} \mathrm{C}$ for claudin 12 , $58^{\circ} \mathrm{C}$ for $\beta$-actin, $59^{\circ} \mathrm{C}$ for claudin $10,60^{\circ} \mathrm{C}$ for claudins 5 and 16 , and of $61^{\circ} \mathrm{C}$ for occludin. The PCR ended with an extension period of $10 \mathrm{~min}$ at $72^{\circ} \mathrm{C}$. In all cases, $\beta$-actin was employed as an internal control. The amplification products were analyzed by electrophoresis in $1.5 \%$ agarose gels stained with ethidium bromide and visualized by transillumination [40]. 


\section{Sequencing and alignment}

The different amplicons were amplified again to obtain the concentration necessary to carry out the sequencing; PCR products were purified with the reagent Exo SAP-IT PCR product cleanup (Thermo Fisher, cat. 78200) and sequenced in the laboratory of Molecular Biochemistry, UBIPRO, FES Iztacala, UNAM. The reported sequences were used to perform a basic alignment in the NCBI Blast program.

\section{Results}

\section{Mucosa}

In adult chickens, the mucous tunic of the different intestinal segments was harvested using the technique of scraping with scalpel blade, and verification by routine histological processing and stained with $\mathrm{H}-\mathrm{E}$ was performed. As can be seen, only the components of the mucous tunic and no other structural component are appreciated (Figure 1).

\section{Characteristics of purified RNA}

All RNAs obtained were evaluated by spectrophotometry. In adult chickens, the concentrations obtained were between 70.9 and $1398.7 \mathrm{ng} / \mathrm{ml}$, while in embryos they were between 1137.9 and $2002.4 \mathrm{ng} / \mathrm{ml}$. Consistently, a greater concentration of RNA was obtained from the embryos than in adult chickens because in the embryos we take the four structural tunics of the intestinal portions, while in adult chickens only the mucous tunic. To know the degree of purity, the ratio of the readings $260 / 280 \mathrm{~nm}$ was determined, the values obtained were in the range of $2.0-2.5$, which shows high purity of isolated RNA (Table 1 and Table 2). The values obtained allow us to consider that the purification method was adequate. Finally, all samples were subjected to electrophoresis in agarose gels and in all of them, the bands corresponding to ribosomal RNA were observed (data not shown).

\section{Amplification of the fragments by RT-PCR}

The products expected for each of the genes under study were obtained by end-point RT-PCR, both for the positive control (chicken embryos) and the

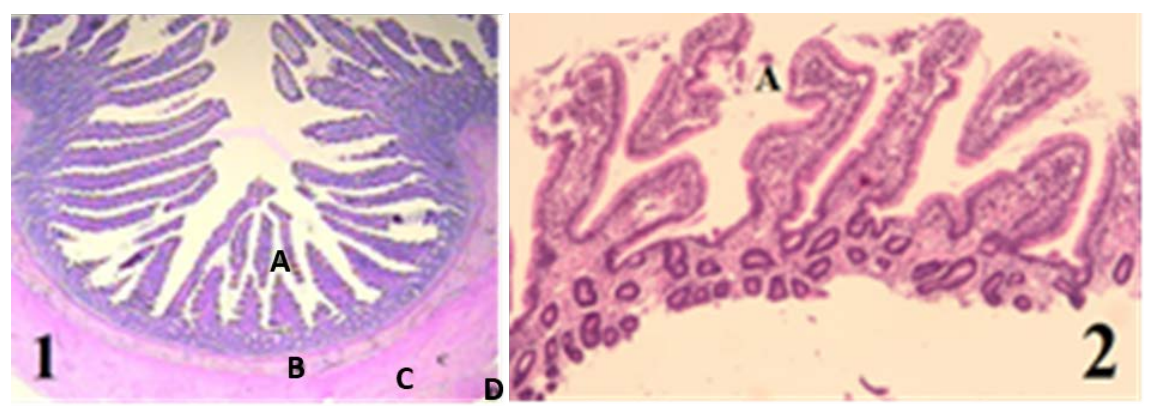

Figure 1. Ileum portion of the domestic chicken. 1. Tunics that form the small intestine: mucous tunic (A), submucosa (B), muscular tunic (C) and serous tunic (D). Harris' haematoxylin-Eosin (HE), 40×. 2. Mucosal tunic recovered by scraping with a scalpel blade you can see its villi and crypts. (A), none of the other tunics can be detected. HE, 200×. 
problem samples (intestinal mucosa of adult chicken). The amplicon of internal control ( $\beta$-actin) is also shown. Obtained fragments were evidenced by electrophoresis in $1.5 \%$ agarose gels (Figure 2). Amplicons of the expected size were obtained for every analyzed sample for each protein of interest; claudin 1 (662 $\mathrm{pb})$, claudin $2(162 \mathrm{pb})$, claudin $3(185 \mathrm{pb})$, claudin 5 (224 pb), claudin 10 (687 $\mathrm{pb})$, claudin $12(738 \mathrm{pb})$, claudin $16(191 \mathrm{pb})$, occludin (430 pb) and $\beta$-actin (331 $\mathrm{pb}$ ) (Figure 2).

\section{Blast alignment}

The reported sequences had the necessary characteristics to perform the basic alignment in the Blast program, $100 \%$ of identity, concerning the expected gene for all samples was found, so we can say that the obtained amplicons correspond to the indicated genes.

\section{Discussion}

Karcher et al. (2008) [8] report that $90 \%$ of the nutrients are absorbed by paracellular transit in the epithelium of the small intestine in birds. In a previous job, we determined that the avian intestinal tract has villi throughout its length [37], suggesting that the cecum and rectum also participate in the absorption process. For this reason, we considered necessary to include these organs in the present study. In this work, we determined the presence of the mRNAs of the proteins studied in all portions of the intestine, both in chicken embryos and 7-week-old

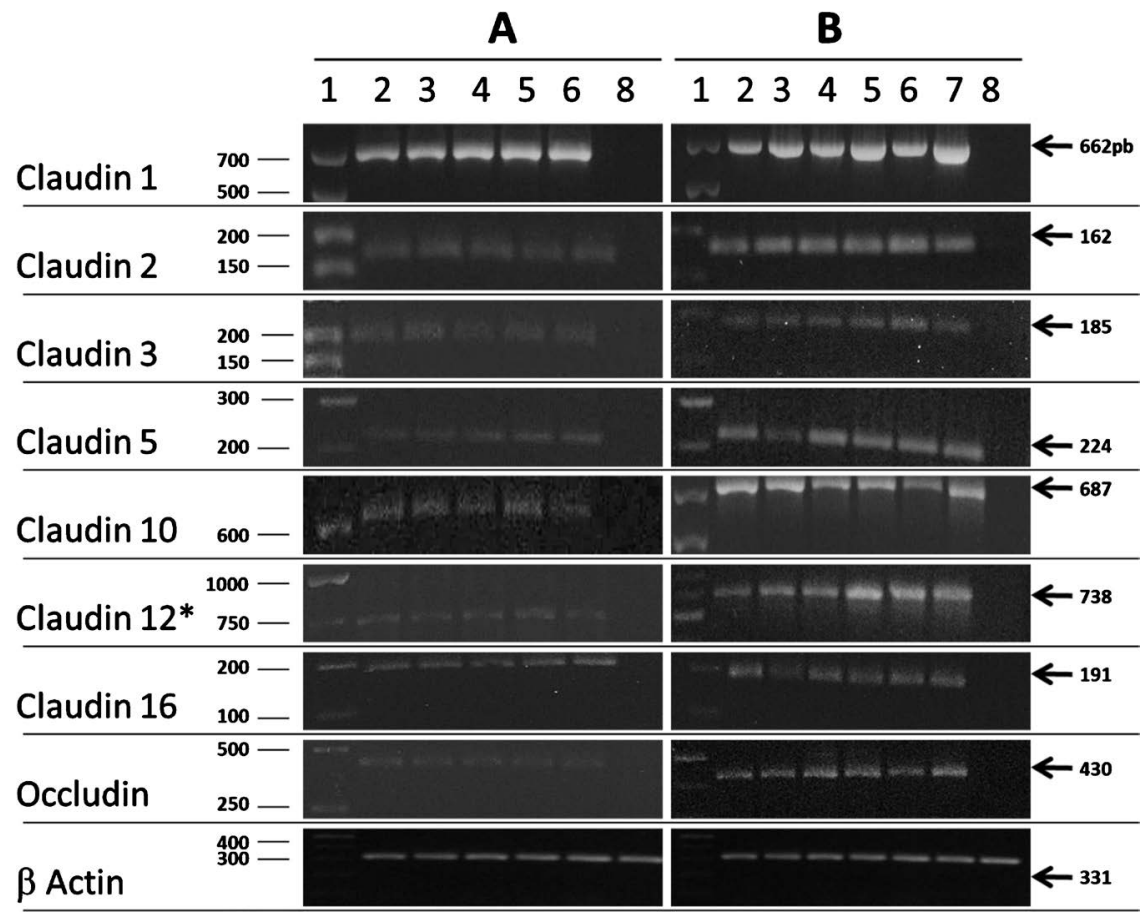

Figure 2. Presence of the mRNA of proteins of tight junctions in an embryo of 16 days (A) and chickens of 7 weeks of age (B). 1. DNA ladder (pb), 2. Duodenum, 3. Jejunum, 4. Ileum, 5. Cecum, 6. Rectum, 7. Positive control (embryo of 16 days). 8. Negative control. Agarose gel $1.5 \%$ stained with ethidium bromide. ${ }^{*}$ The DNA ladder in group B is: 600 , 700 and $800 \mathrm{pb}$. 
broiler. This evidence supports the hypothesis that the cecum and rectum, not only have a histological resemblance to the small intestine but they also seem to be involved in nutrient absorption. Additionally, the intestinal epithelium forms a protective barrier that depends on the presence of tight junctions. The barrier function regulates the passage of molecules at the intercellular level and maintains a boundary between the apical and basolateral domains of the plasma membrane of the epithelial cells [6].

Intestinal absorption is a complex process in birds and to understand it is essential a deep knowledge of the tight junctions, so the objective of this work was to determine the presence of the mRNA of the proteins involved in these junctions; occludin and claudins $-1,-2,-3,-5,-10,-12$ and -16 in the mucous tunic of the different segments of the intestinal tract of an adult chicken. This is the first paper in which the expression of these proteins in all portions of the intestinal tract in adult chickens is reported. It should be noted that its expression was equal to that determined in a 16-day-old chicken embryo which supports the hypothesis that the expression of these proteins in the mucosa of the intestinal tract is maintained in adult animals [3] [39] [41]. Although recently, age-related changes have been reported in the expression level of claudins 1, 3, 5, 7,10 , and 19 in the jejunum and cecum in chickens [15].

The proteins studied here can be grouped in barrier formers and those involved in channel function. Within the first group we have, claudins $1,2,3$, and 5, and occludin [41] [42].

Claudin 1 has been encountered in most of the epithelial tissues studied [41] [42]. In mammals, specifically in mice, the expression profiles of claudin 1 are known in the different segments of the intestinal tract [19] [20] [43], this makes it possible to highlight this coincidence with the results obtained in this work and to relate them to the function of this protein because it is fundamental for the formation of tight junctions in different species. Claudin 3 is expressed in a wide variety of epithelium, it is present along the gastrointestinal tract, mainly in duodenum, jejunum, and ileum of mouse, rat, fish, and embryos in different stages of development [3] [19] [39] [44] and ileum and cecum of chickens [16]. The latter is consistent with our results, although we also found it to be present in duodenum, jejunum, and rectum.

Claudin 5 is expressed predominantly in the endothelium and has been reported in the intestinal epithelium of adult rats and mice [19] [20] [43]; as well as in different periods of embryonic development, in the small intestine epithelium in chickens [39], and the blood-brain barrier [45]. In this study, the presence of mRNA of claudin 5 was determined in all intestinal segments studied, both in the embryo and in adult birds.

Occludin is a fundamental component of tight junctions in many vertebrate cells and tissues since it participates in the barrier function and contributes to their stabilization. In this work, it was possible to determine for the first time the expression of occludin mRNA in the entire intestinal tract of the domestic 
chicken from 7 weeks of age.

Claudins 2, 10, 12, and 16 are proteins that form channels. Claudin 2 is present in epithelial tissues and intestinal crypts in chicken and mammalian embryos [3] [43] [44]. Zhang et al. (2013) [19], reported that in mice it is expressed throughout the gastrointestinal tract, where it was found at the bottom of the crypts. Its presence has also been reported in the duodenum and jejunum of laying hens, where it participates in the absorption of calcium by paracellular route [17]. We found it in all intestinal segments of the birds under study. Claudin 10 is expressed in renal tubules, kidney medulla, and intestines [42]. In the present study, the presence of mRNA for claudin 10, in the duodenum, jejunum, and ileum of embryos was observed, which coincides with that reported by Collins et al. (2013) [3]. Additionally, was also observed in the cecum and rectum, where had not been reported yet. Claudin 12 is expressed mainly in the intestinal epithelium, it intervenes during the paracellular absorption of calcium-dependent on vitamin D. In this work, it was found in all the intestinal segments in embryos of 16 days of age and animals of 7 weeks of age. Claudin 16 has been reported in the renal epithelium, where it participates in the paracellular transport of divalent cations [42]. Ozden et al., (2010) [39] report its presence in the intestinal epithelium of chicken embryos with 20 days of incubation, mainly in the caliciform cells found near the apex of the villi, and relate it to the maturation of this tissue. Coinciding with our results, other authors have reported the expression of this protein in the duodenum, jejunum and, ileum. In addition, our study also reports it in the cecum and rectum. The presence of claudin 16 in these intestinal segments seems to justify their function as they participate in the absorption of water and minerals.

It is important to note that all the claudins studied in this work were present in all the segments analyzed in the small and large intestines of chickens while in mammals a differential expression of these claudins is reported between the small intestine (claudins $1,2,3,4,7,8,12,13$ and 15) and the large intestine (claudins 1, 3, 4, 7, 8, 12, 13 and 15) [18].

It has been reported that tight junctions are not permanent, but are selectively regulated with their permeability capacity, so their components are exchanged according to the required function. The remodeling of these junctions is performed by endocytosis and degradation of claudins [1] [46] [47] [48].

The study of the proteins that form the tight junctions will allow us to better understand the mechanism that regulate their modification in the different physiological and pathological states of the intestine, particularly in the absorption processes where birds preferentially use the paracellular pathway. It will also allow us to understand the effect of vitamins and/or probiotics on tight junctions and their impact on the health of the intestinal tract of birds. For example, it is reported that the administration of probiotics induces the expression of claudin 1,2 , and 5, favoring intestinal absorption in chickens, although the mechanisms involved are not known [49] [50] [51] [52]. 
On the other hand, we will understand how the close junctions are affected by specific pathogens of the intestinal tract, either by direct interaction with intestinal cells or by their toxins. It would also allow the generation of new therapeutic strategies against this type of disease [53]-[59].

\section{Conclusion}

This work is the first report about the mRNA expression of proteins involved in the formation of tight junctions (occludin and claudins $1,2,3,5,10,12,16$ ) in the mucous tunic of all portions of the small and large intestine (duodenum, jejunum, ileum, cecum, and rectus) in the chicken (Gallus gallus domesticus). These findings will allow us to further elucidate the specific function of each of the studied proteins in the process of paracellular absorption in adult chickens.

\section{Acknowledgements}

We are grateful to the Consejo Nacional de Ciencia y Tecnología (CONACYT) México forgrant \# 301233, afforded for the carrying out of Master in Science studies (Elizabeth Aguire García), as well as for the support given by the project PIAPI 2050 (FES-Cuautitlán UNAM).

\section{Conflicts of Interest}

The authors declare no conflicts of interest regarding the publication of this paper.

\section{References}

[1] Tsukita, S., Tanaka, H. and Tamura, A. (2019) The Claudins: From Tight Junctions to Biological Systems. Trends in Biochemical Science, 44, 141-152. https://doi.org/10.1016/j.tibs.2018.09.008

[2] Furuse, M. (2010) Chapter 1 Introduction: Claudins, Tight Junctions, and the Paracellular Barrier. In: Yu, A.S.L., Ed., Current Topics in Membranes, Vol. 65, Elsevier, Boston, 1-19. https://doi.org/10.1016/S1063-5823(10)65001-6

[3] Collins, M., Baumholtz, A. and Ryan, A. (2013) Claudin Family Members Exhibit Unique Temporal and Spatial Expression Boundaries in the Chick Embryo. Tissue Barriers, 1, e24517. https://doi.org/10.4161/tisb.24517

[4] Capaldo, C.T. and Nusrat, A. (2015) Claudin Switching: Physiological Plasticity of the Tight Junction. Seminars in Cell and Developmental Biology, 42, 22-29. https://doi.org/10.1016/j.semcdb.2015.04.003

[5] Wada, M., Tamura, A., Takahashi, N. and Tsukita, S. (2013) Loss of Claudins 2 and 15 from Mice Causes Defects in Paracellular $\mathrm{Na}^{+}$Flow and Nutrient Transport in Gut and Leads to Death from Malnutrition. Gastroenterology, 144, 369-380. https://doi.org/10.1053/j.gastro.2012.10.035

[6] Alberts, B., Johnson, A., Lewis, J., Morgan, D., Raff, M., Roberts, K. and Walter, P. (2015) Molecular Biology of the Cell. 6th Edition, Garland Science, New York.

[7] Elkouby-Naor, L. and Ben-Yosef, T. (2010) Functions of Claudin Tight Junction Proteins and Their Complex Interactions in Various Physiological Systems. International Review of Cell and Molecular Biology, 279, 1-32. 
https://doi.org/10.1016/S1937-6448(10)79001-8

[8] Karcher, D.M. and Applegate, T. (2008) Survey of Enterocyte Morphology and Tight Junction Formation in the Small Intestine of Avian Embryos. Poultry Science, 87, 339-350. https://doi.org/10.3382/ps.2007-00342

[9] Hideki, C., Makoto, O., Masaki, M., Takashi, K. and Norimasa, S. (2007) Transmembrane Proteins of Tight Junctions. Biochimica et Biophysica Acta, 1778, 588-600. https://doi.org/10.1016/j.bbamem.2007.08.017

[10] Fanning, A.S., Mitic, L.L. and Anderson, J.M. (1999) Transmembrane Proteins in the Tight Junction Barrier. Journal of the American Society of Nephrology, 10, 1337-1345. https://pubmed.ncbi.nlm.nih.gov/10361874 https://doi.org/10.1681/ASN.V1061337

[11] Anderson, J.M. and Van Itallie, C.M. (1995) Tight Junctions and the Molecular Basis for Regulation of Paracellular Permeability. Journal of Physiology, 269, G467-G475. https://doi.org/10.1152/ajpgi.1995.269.4.G467

[12] Assimakopoulos, S.F. (2011) Enterocytes Tight Junctions: From Molecules to Diseases. World Journal Gastrointestinal Pathophysiology, 2, 123-137.

https://doi.org/10.4291/wjgp.v2.i6.123

[13] Angelow, S., Ahlstrom, R. and Yu, AS. (2008) Biology of Claudins. American Journal of Physiology-Renal Physiology, 295, F867-F876.

https://doi.org/10.1152/ajprenal.90264.2008

[14] Fujita, H., Chiba, H., Yokozaki, H., Sakai, N., Sugimoto, K., Wada, T., Kojima, T., Yamashita, T. and Sawada, N. (2006) Differential Expression and Subcellular Localization of Claudin-7, $-8,-21,-13$, and -15 along the Mouse Intestine. Journal of Histochemistry and Cytochemistry, 54, 933-944. https://doi.org/10.1369/jhc.6A6944.2006

[15] Von Buchholz, J.S., Bilic, I., Aschenbach, J.R., Hess, M., Mitra, T. and Awad, W.A. (2021) Establishment of a Novel Probe-Based Rtqpcr Approach for Detection and Quantification of Tight Junctions Reveals Age-related Changes in the Gut Barriers of Broiler Chickens. PLOS ONE, 16, e0248165. https://doi.org/10.1371/journal.pone.0248165

[16] Hollemans, M.S., van Baal, J., de Vries, Reilingh, G., Kemp, B., Lammers, A. and de Vries, S. (2020) Intestinal Epithelium Integrity after Delayed Onset of Nutrition in Broiler Chickens. Poultry Science, 99, 6818-6827. https://doi.org/10.1016/j.psj.2020.08.079

[17] Gloux, A., Le Roy, N, Brionne, A., Bonin, E., Juanchich, A., Benzoni, G., Piketty, M.L., Prié, D., Nys, Y., Gautron, J., Narcy, A. and Duclos, M.J. (2019) Candidate Genes of the Transcellular and Paracellular Calcium Absorption Pathways in the Small Intestine of Laying Hens. Poultry Science, 98, 6005-6018.

https://doi.org/10.3382/ps/pez407

[18] Kim, D.Y., Furuta, G.T., Nguyen, N., Inage, E. and Masterson, J.C. (2019) Epithelial Claudin Proteins and their Role in Gastrointestinal Diseases. Journal of Pediatric Gastroenterology Nutrition, 68, 611-614. https://doi.org/10.1097/MPG.0000000000002301

[19] Zhang, Z., Wang, H., Sun, Y., Li, H. and Wang, N. (2013) Klf7 Modulates the Differentiation and Proliferation of Chicken Preadipocyte. Acta Biochimica Biophysica Sinica, 45, 280-288. https://doi.org/10.1093/abbs/gmt010

[20] Amasheh, S., Fromm, M. and Günzel, D. (2011) Claudins of Intestine and Nephron-A Correlation of Molecular Tight Junction Structure and Barrier Function. Acta Physiological, 201, 133-140. https://doi.org/10.1111/j.1748-1716.2010.02148.x 
[21] Yu, A.S., Cheng, M.H., Angelow, S., Gunzel, D., Kanzawa, S.A., Schneeberger, E.E., Fromm, M. and Coalson, R.D. (2009) Molecular Basis for Cation Selectivity in Claudin-2-Based Paracellular Pores: Identification of an Electrostatic Interaction Site. Journal of General Physiology, 133, 111-127. https://doi.org/10.1085/jgp.200810154

[22] González-Mariscal, L., Betanzos, A., Nava, P. and Jaramillo, B.E. (2003) Tight Junction Proteins. Progress in Biophysics and Molecular Biology, 81, 1-44. https://doi.org/10.1016/S0079-6107(02)00037-8

[23] Tsukita, S. and Furuse, M. (2000) Pores in the Wall: Claudins Constitute Tight Junction Strands Containing Aqueous Pores. Journal of Cell Biology, 149, 13-16. https://doi.org/10.1083/jcb.149.1.13

[24] Baumholtz A.I., Gupta, I.R. and Ryan, A.K. (2017) Claudins in Morphogenesis: Forming an Epithelial Tube. Tissue Barriers, 5, e1361899.

https://doi.org/10.1080/21688370.2017.1361899

[25] Muresan, Z., Paul, D.L. and Goodenough, D.A. (2000) Occludin 1B, a Variant of the Tight Junction Protein Occludin. Molecular Biology of the Cell, 11, 627-634. https://doi.org/10.1091/mbc.11.2.627

[26] Yakey, Y., Shepshelovitch, J., Nevo-Yassaf, I., Yeheskel, A., Shmerling, H., Kwiatek, J.M., Gaus, K., Pasmanik-Chor, M. and Hirschberg, K. (2012) The MARVEL Transmembrane Motif of Occludin Mediates Oligomerization and Targeting to the Basolateral Surface in Epithelia. Journal of Cell Science, 125, 3545-3556.

[27] Lapierre, L. (2000) The Molecular Structure of the Tight Junction. Advanced Drug Delivery Reviews, 41, 255-264. https://doi.org/10.1016/S0169-409X(00)00045-4

[28] Furuse, M., Hirase, T., Itoh, M., Nagafuchi, A., Yonemura, S., Tsukita, S. and Tsukita, S. (1993) Occludin: A Novel Integral Membrane Protein Localizing at Tight Junctions. Journal of Cell Biology, 123, 1777-1788. https://doi.org/10.1083/jcb.123.6.1777

[29] Wang, Y., Liu, Y., Sidhu, A., Ma, Z., McClain, C. and Feng, W. (2012) Lactobacillus rhamnosus GG Culture Supernatant Ameliorates Acute Alcohol-Induced Intestinal Permeability and Liver Injury. American Journal Physiologic Gastrointestinal Liver Physiology, 303, G32-G41. https://doi.org/10.1152/ajpgi.00024.2012

[30] Furuse, M. and Tsukita, S. (2006) Claudins in Occluding Junctions of Humans and Flies. Trends in Cell Biology, 16, 181-188. https://doi.org/10.1016/j.tcb.2006.02.006

[31] Anderson, J.M., Van Itallie, C.M. and Fanning, A.S. (2004) Setting Up a Selective Barrier at the Apical Junction Complex. Current Opinion in Cell Biology, 16, 140-145. https://doi.org/10.1016/j.ceb.2004.01.005

[32] Li, J., Angelow, S., Linge, A., Zhuo, M. and Yu, A.S. (2013) Claudin-2 Pore Function Requires an Intramolecular Disulfide Bond Between Two Conserved Extracelular Cysteines. American Journal of Physiology-Cell Physiology, 305, C190-C196. https://doi.org/10.1152/ajpcell.00074.2013

[33] Angelow, S. and Yu, A.S. (2009) Cysteine Mutagenesis to Study the Structure of Claudin-2 Paracellular Pores. Annals of the New York Academy of Science, 1165, 143-147. https://doi.org/10.1111/j.1749-6632.2009.04038.x

[34] Konrad, M., Schaller, A., Seelow, D, Pandey, A.V., Waldegger, S., Lesslauer, A., et al. (2006) Mutations in the Tight-Junction Gene Claudin 19 (CLDN19) Are Associated with Renal Magnesium Wasting, Renal Failure and Severe Ocular Involvement. American Journal of Human Genetics, 79, 949-957. https://doi.org/10.1086/508617

[35] Van Itallie, C.M., Rogan, S., Yu, A., Vidal, L.S., Holmes, J. and Anderson, J.M. (2006) Two Splice Variants of Claudin-10 in the Kidney Create Paracellular Pores 
with Different Ion Selectivities. American Journal of Physiology-Renal Physiology, 291, F1288-F1299. https://doi.org/10.1152/ajprenal.00138.2006

[36] Koval, M. (2013) Differential Pathways of Claudin Oligomerization and Integration into Tight Junctions. Tissue Barriers, 1, e24518. https://doi.org/10.4161/tisb.24518

[37] Campos, G.C.A. (2014) Estudio de las poblaciones celulares localizadas en el epitelio de la mucosa del intestino de la gallina doméstica (Gallus gallus domesticus). FES-Cuautitlán UNAM. Tesis de Maestría. México.

[38] Karasov, W.H., Caviedes-Vidal, E., Bakken, B.H., Izhaki, I., Samuni-Blank, M. and Arad, Z. (2012) Capacity for Absorption of Water-Soluble Secondary Metabolites Greater in Birds than in Rodents. PLoS ONE, 7, e32417. https://doi.org/10.1371/journal.pone.0032417

[39] Ozden, O., Black, B.L., Ashwell, C.M., Tipsmark, C.K., Borski, R.J. and Grubb, B.J. (2010) Developmental Profile of Claudin-3, -5, and -16 Proteins in the Epithelium of Chick Intestine. Anatomical Record, 293, 1175-1183. https://doi.org/10.1002/ar.21163

[40] Sambrook, J. and Russel, D. (2001) Molecular Cloning: A Laboratory Manual. Cold Spring Harbor Laboratory Press, New York.

[41] Simard, A., Di Pietro, E. and Ryan, A. (2005) Gene Expression Pattern of Claudin-1 during Chick Embryogenesis. Gene Expression Patterns, 5, 553-560. https://doi.org/10.1016/j.modgep.2004.10.009

[42] Günzel, D. and Yu, A.S.L. (2013) Claudins and the Modulation of Tight Junction Permeability. Physiological Reviews, 93, 525-569.

https://doi.org/10.1152/physrev.00019.2012

[43] Holmes, J.L., Van Itallie, C.M., Rasmussen, J.E. and Anderson, J.M. (2006) Claudin Profiling in the Mouse during Postnatal Intestinal Development and along the Gastrointestinal Tract Reveals Complex Expression Patterns. Gene Expression Patterns, 6, 581-588. https://doi.org/10.1016/j.modgep.2005.12.001

[44] Ozden, O. (2009) Expression of Claudin Tight Junction Proteins in Response to Varying Environmental and Physiological Conditions. Doctoral Thesis, Faculty of North Carolina State University, Raleigh.

[45] Greene, C., Hanley, N. and Campbell, M. (2019) Claudin-5: Gatekeeper of Neurological Function. Fluids and Barriers of the CNS, 16, 1-15.

https://doi.org/10.1186/s12987-019-0123-Z

[46] Weber, C.R., Liang, G.H., Wang, Y., Das, S., Shen, L., Yu, A.S., Nelson, D.J. and Turner, J.R. (2015) Claudin-2-Dependent Paracellular Channels Are Dynamically Gated. Elife, 4, e09906. https://doi.org/10.7554/eLife.09906

[47] Shen, L., Weber, C.R., Raleigh, D.R., Yu, D. and Turner, J.R. (2011) Tight Junction Pore and Leak Pathways: A Dynamic Duo. Annual Review of Physiology, 73, 283-309. https://doi.org/10.1146/annurev-physiol-012110-142150

[48] Takahashi, S., Iwamoto, N., Sasaki, J., Ohashi, M., Oda, Y., Shoichiro, T. and Furuse, M. (2008) The E3 Ubiquitin Ligase LNX1p80 Promotes the Removal of Claudins from Tight Junctions in MDCK Cells. Journal of Cell Science, 122, 985-994. https://doi.org/10.1242/jcs.040055

[49] Yang, C., Liu, Y., Yan, F., Yang, C. and Yang, X. (2019) Effects of Encapsulated Organic Acids and Essential Oils on Intestinal Barrier, Microbial Count, and Bacterial Metabolites in Broiler Chickens. Poultry Science, 98, 2858-2865.

https://doi.org/10.3382/ps/pez031

[50] Cheng, Y., Xu, Q., Chen, Y., Su, Y., Wen, C. and Zhou, Y. (2018) Modified Paly- 
gorskite Improves Immunity, Antioxidant Ability, Intestinal Morphology, and Barrier Function in Broiler Chickens Fed Naturally Contaminated Diet with Permitted Feed Concentrations of Fusarium Mycotoxins. Toxins, 10, 482.

https://doi.org/10.3390/toxins10110482

[51] Liu, S.D., Song, M.H., Yun, W., Lee, J.H., Lee, C.H., Kwak, W.G., Han, N.S., Kim, H.B. and Cho, J.H. (2018) Effects of Oral Administration of Different Dosages of Carvacrol Essential Oils on Intestinal Barrier Function in Broilers. Journal of Animal Physiology and Animal Nutrition, 102, 1257-1265.

https://doi.org/10.1111/jpn.12944

[52] Wang, Y., Wang, Y., Xu, H., Mei, X., Gong, L., Wang, B., Li, W. and Jiang, S. (2018) Direct-Fed Glucose Oxidase and Its Combination with B. amyloliquefaciens SC06 on Growth Performance, Meat Quality, Intestinal Barrier, Antioxidative Status, and Immunity of Yellow-Feathered Broilers. Poultry Science, 97, 3540-3549. https://doi.org/10.3382/ps/pey216

[53] Sharafutdinov, I., Esmaeili, D.S., Harrer, A., Tegtmeyer, N., Sticht, H. and Backert, S. (2020) Campylobacter Jejuni Serine Protease Htra Cleaves the Tight Junction Component Claudin-8. Frontiers in Cellular and Infection Microbiology, 10, Article ID: 590186 https://doi.org/10.3389/fcimb.2020.590186

[54] Hongxin, L., Liu, X., Chen, F., Zuo, K., Wu, C., Yan, Y., Chen, W., Lin, W. and Xie, Q. (2018) Avian Influenza Virus Subtype H9N2 Affects Intestinal Microbiota, Barrier Structure Injury, and Inflammatory Intestinal Disease in the Chicken Ileum. Viruses, 10, 270. https://doi.org/10.3390/v10050270

[55] Awad, W.A., Hess, C. and Hess, M. (2017) Enteric Pathogens and Their Toxin-Induced Disruption of the Intestinal Barrier through Alteration of Tight Junctions in Chickens. Toxins, 9, 60. https://doi.org/10.3390/toxins9020060

[56] Berkes, J., Viswanathan, V.K., Savkovic, S.D. and Hecht, G. (2003) Intestinal Epithelial Responses to Enteric Pathogens: Effects on the Tight Junction Barrier, Ion Transport, and Inflammation. Gut, 52, 439-451. https://doi.org/10.1136/gut.52.3.439

[57] Vidal, G.J. (2003) Escherichia coli enteropatógena (EPEC): Una causa frecuente de diarrea infantil. Salud en Tabasco (en línea), 9, 188-193. https://www.redalyc.org/articulo.oa?id=48709108

[58] Sears, C. (2000) Molecular Physiology and Pathophysiology of Tight Junctions V. Assault of the Tight Junction by Enteric Pathogens. American Journal of Physiology-Gastrointestinal and Liver Physiology, 279, G1129-G1134. https://doi.org/10.1152/ajpgi.2000.279.6.G1129

[59] Uzzau, S. and Fasano, A. (2000) Cross-Talk between Enteric Pathogens and the Intestine. Cell Microbiology, 2, 83-89.

https://doi.org/10.1046/j.1462-5822.2000.00041.x 